ERnst PIJNING

Obtuvo el grado de maestría en la Universidad de Leiden, Holanda y el de doctor por la Universidad Johns Hopkins, actualmente es docente en la Univesidad de Minot State en Dakota

del Norte, Estados Unidos. Sus principales líneas de investigación se refieren al contrabando en el Brasil colonial y al comercio internacional. Ha publicado en varias revistas internacionales tales como: The Hispanic American Historical Revieve, Revista Brasileira de Historia e Itinerario. 


\title{
SOURCES AND HISTORIOGRAPHY: CONCEPTUALIZATIONS OF CONTRABAND TRADE IN COLONIAL BRAZIL
}

\author{
Ernst Pijning*
}

$\mathrm{S}$ muggling is a difficult topic for Brazilian historians. No historian of colonial Brazil has devoted a book solely to the topic of contraband trade yet. The reason for this is partly related to the supposed lack of documentation about this issue. ${ }^{1}$ This problem with sources notwithstanding, historians have debated the importance of contraband trade. Their understanding of illegal trade has changed over time, and many historians' views of colonial society in general, and smuggling in particular, is closely related to how Brazilians consider themselves.

Brazil is not the only country where illegal trade was equated to national identity. The case of the United States combining smuggling with national heroism is instructive. The idea that the Boston Tea Party was an act of liberation against British oppression is deeply ingrained in United States history. That smuggling at the center of Bostonian merchants' complaints, was not contradictory to the ideal of "liberty". ${ }^{2}$ However, whenever smuggling deals with "the other," the story is quite different. When smuggling takes place in the Northern Mexican borderlands, United States historians view this as a form of weakness and a legitimation of Spain's loss of political control over this area. ${ }^{3}$ Contraband trade becomes more than breaking the law; indeed, how historians understand this

* Minot State University. I would like to thank Shaun Anne Tangney for her corrections of my English, and the two anonymous reviewers for their comments and suggestions.

${ }^{1}$ Bernstein, Brazilian, 1986, p. 3.

${ }^{2}$ Tyler, Smugglers, 1986

${ }^{3}$ Weber, Spanish, 1992, pp. 174-175. Weber is just one supporter of these ideas arguing that Spanish economic weakness cause the lack of provisions to the desolated borderlands, and AmÉrica LATina en la Historia Económica númeto 24, julio-diciembre de 2005 
phenomenon depends on their geo-political ideas, as does their selection of sources for such a study. ${ }^{4}$

Historians are source driven; understanding their sources of information explains their interpretations. I will show how different generations of historians have been influenced by the sources that they use. Thus I will distinguish between five different periods: in the first, the writers of the colonial past had few opportunities to write without censorship about illegal activities. In the second, nineteenth-century historians were engaged in positivist writing, and preferred to be informational rather than interpretative. These historians were writing for future generations who in their turn can interpret their sources themselves. In the third, the pre-World War II generation become more romantic, as Brazilian history becomes more introverted and concerned with what it means to be a Brazilian. In the fourth, post-World War II generation, when history becomes more structuralist and Marxist, mostly in opposition to the military regimes, interpreting Brazil's inhabitants as casualties of colonial exploitation. In the fifth, the postmodern period, more subaltern-oriented historians reclaimed Brazilian's autonomy in economic activities. In this essay, smuggling is the theme of the overview of historiography of colonial Brazil. However, given the tendency to integrate contraband trade with colonial society as a whole, most conclusions will be valid for colonial Brazil or indeed colonial Latin America.

The first generations of Brazilian writers had enormous obstacles to face. Unlike Spanish America, Brazil did not possess a printing press or a university. All works about Brazil had to be printed in Portugal and were therefore more oriented towards a metropolitan audience. Moreover, all publications had to be authorized by the censors, representatives of the king and of the Church. Any administrative or religious career had to begin by entering a Portuguese university, since no institutions of higher education existed in Brazil before the arrival of the Portuguese court in Brazil in 1808.

Given these facts, it will not come as a surprise that the earliest publications on colonial Brazil were Portuguese-centered. Brazil was part of the Portuguese empire and was not considered separately. ${ }^{5}$ The earliest accounts of the colonies were therefore related to territories under Portuguese administration elsewhere, especially in India. Practices in administration and commerce in India predated those in Brazil by more than a century, and it was logical that Portuguese merchants and readers connected

paraphrasing an author who charged the Spanish as being "indolent." For more on this idea, see Kagan, "Prescott's", 1996.

Pijning, "Controlling", 1997.

${ }^{5}$ For a good bibliography on publications of the colonial era, see Borba, Bibliographia, 1983. 
Brazilian practices with those in India. Critique on Portuguese colonial administration came from the most distinguished echelons of society, and in Portuguese India this critique was made by Diogo do Couto.

Diogo do Couto was the official historian of Portuguese expansion overseas. He inherited the works of his predecessor, João de Barros, who started a list of the Portuguese heroic deeds in the Décadas da Asia. As the keeper of the Goan archives and a former employee in Asia, Diogo do Couto had access to many official sources, and he could draw on his own memories. Based on these materials, Do Couto's legacy folds in two major publications: the official story as laid down in Da Asia and the unofficial story as told in his O Soldado Prático (The Experienced Soldier). The latter was not published until 1790, but the manuscript circulated among his contemporaries. ${ }^{6}$

$O$ Soldado Prático was a book by a frustrated historian. The book itself is not about illegal trade per se; rather, it explains the problematic governance of Portuguese India. When the book was written, Portuguese India was in decline, and Diogo do Couto wanted to point out the circumstances that led to its downfall and how to remedy these. Corruption rather than smuggling was the main problem in far away Asia, but that corruption encompassed the failure to pay correct taxes at the Customs. ${ }^{7}$ Diogo do Couto's dialog has in common with many accounts on the perversion of Portuguese administration over its colonies his beliefs that bad administration led to decadence of the empire which he considered a Divine punishment. ${ }^{8}$

Arte de Furtar (The Art of Thieving) elaborates on the Diogo do Couto's problems in India. It deals with corruption in Portugal at the turn of the eighteenth century. Meant to be sarcastic, the author explains how corruption has reached every level of Portuguese society, from a yeoman to the king. Like in India, the author assumes that the greatest thieves are the persons supposed to prevent this crime, whether these are judges, noblemen, clergy, or officials of the customs. ${ }^{9}$ The message from India and Portugal is clear: illegal trade should be considered at the same level as corruption and thieving, or both are deeply ingrained in Portuguese administration and society. However, can one assume the same about Portuguese America?

Whereas the treatises on Portuguese India and Portugal warned the readers of the deeply ingrained abuses and explained them as a

${ }^{6}$ Couto, Soldado, 1980, pp. 9-13, and Winius, Black, 1985, pp. 9-10.

"Winius, Black, 1985, p. 33, based on Pyrard de Laval's travel account.

Ioid., p. 23.

Bisnut, Arte, 1991. 
manifestation of worldly and spiritual downfall, the first histories of Brazil remained more informative, giving reasons to attract colonists to the newly encountered world. Portuguese inhabitants of Brazil authored several firsthand accounts on the Amerindians (and their conversion), the fertility of the land, and the activities of the first settlers. One of these books was written by Pero de Magalhães Gândavo, a friend of Luís de Camões, who elaborates on the history of the province of Santa Cruz (the name Cabral gave to Brazil). ${ }^{10}$ Apart from relating the most recent history of Portuguese Brazil from the arrival of Cabral to the $1570 \mathrm{~s}$, the book also explains that the Province of Santa Cruz is a very fertile land, open to colonists who will encounter gold and gems in the interior. The book details the sites of most Portuguese settlements, elaborates on its economies and outlines its relations with the local populations. In similar terms Ambrósio Fernandes Brandão wrote optimistically in the late sixteenth-century account of Brazil. The New Christian Sugar Mill owner argued that even though banished criminals were exiled to Brazil in the first decades, the lust for opportunity ennobled its settler population. ${ }^{11}$ This book not only served as a propaganda tool to attract new Portuguese settlers, it was also used as a guide for Dutch, English, French, and Spanish competitors.

Given the subsequent wars with the Dutch republic and with France, one can imagine that not all these publications were welcomed by the Portuguese crown. Indeed, one of the most important treatises was immediately forbidden and all copies taken out of circulation. The prime example of a forbidden book is Antonil's (assumed to be the pseudonym for João António Andreoni, S. J.) Cultura e Opulência das Drogas do Brasil published in 1711, and immediately taken out of circulation. The book details four major economic activities in the Portuguese colony: the cultivation of sugar and tobacco, gold mining, and cattle herding. ${ }^{12}$ The book minutely describes the methods of cultivation and mining, their finances, and the interior of Brazil including some maps. However, after several foreign invasions at the end of the War of Spanish Succession that led to the brief occupation of Rio de Janeiro by a French fleet in 1711, the Portuguese administration was quite reluctant to make such information public. Gold was found in Brazil during the $1690 \mathrm{~s}$, and this made the colony even more attractive to European competition, which the Portuguese king did not wish to encourage.

Antonil was the first to put the issue of illegal trade to print. Especially in the case of tobacco cultivation and gold mining he explained what

${ }^{10}$ Magalhães, História, 1984; Vaifas, Dicionário, 2000, p. 482

Fernandes, Dialogues, 1987 , p. 148.

${ }_{12}$ The best edition is Antonil, Cullura, 1965. 
would happen if farmers and miners refused to pay the full taxes on their products. According to Antonil, the king had a natural right to this taxation, and in the end transgressors would be caught, have their goods confiscated, and leave their families in poverty. ${ }^{13}$ His work legitimized the Portuguese administration over Brazil and explained the consequences for those who did not obey the king's rules. Antonil's book is the best contemporary witness of Brazil's economy and it has been widely used by historians of the eighteenth century.

Historians have used two types of publications for their sources on the economy and society of eighteenth-century Brazil. The first are memoranda written to improve the Brazilian economy by Portuguese and Brazilian authors, and the second are foreign travel accounts by visitors to Brazilian harbors. Both are similar, since in the eighteenth century travelers were educated informants and members of scientific academies. These foreign visitors were most willing to comment on the state of Brazilian development and how to make improvements. ${ }^{14}$ Subsequently, the Brazilian and Portuguese authors of memoranda had read these foreign travel accounts and took their recommendations at heart.

Scientific societies reached Brazil and Portugal during the eighteenth century. Local elites ran these organizations to promote the arts, letters, and the economy. Their members promoted themselves and their local community through the presentation of memoranda, musing on their illustrious past and promoting future development of the economy. Educated officials were highly represented in these organizations, and they tried to improve their status by sending these memoranda to the Overseas Council, the secretary of state, and the Sovereign in Lisbon.

By the late eighteenth-century these memoranda became fashionable. Several were published in the annals of the Lisbon Academy of Sciences to which several university educated Brazilians contributed..$^{15}$ As illegal trade was rife in that period, it was addressed in order to improve revenues, the local economies, and Brazilian allegiance to Portugal. Most memoranda dealt with the utilization of natural resources for economic purposes. For instance, Balthazar da Silva Lisboa, a crown judge, wrote extensively about conservation and utilization of several types of wood. ${ }^{16}$ His brother, José da Silva Lisboa, wrote extensively about the liberalization of the Brazilian economy and the elimination of crown monopolies. ${ }^{17}$ The Bishop

${ }^{19}$ Ibid., pp. 336-338 and 416

Bradford, "Intellectuals", 1975

The earliest volumes have been republished recently as Memórias, 1990-1991.

${ }^{16}$ On Balthazar da Silva Lisboa's activities in Southern Bahia see Miller, Fruitless, 2000, esp. 54-57. of the Arquivo Histórico Ultramarino. 
of Pernambuco, José Joaquim da Cunha de Azeredo Coutinho was likewise engaged in the transformation of the regulatory system of the Brazilian economy in order to promote growth, which was all the much more surprising given his family's long lasting ties with the Portuguese regime. The later secretary of state Dom Rodrigo de Souza Coutinho did likewise. ${ }^{18}$ The works of these statesmen were signs of loyalty. Their primary goals were to improve the economic and political relationships between colony and mother country, in a time when smuggling increased dramatically and signs of Brazilian resistance to Portuguese overlordship became more obvious.

Not all officials were so loyal as the four statesmen above. However, literary works from Gregório de Matos and Tomás António Gonzaga were extremely satirical and fully blamed the incompetence of Portuguese administrators for the failure of Brazilian economy. Both had to pay dearly for their comments: one was exiled to Angola, the other to Mozambique after conspiring to overthrow the government of the Mining districts. ${ }^{19}$

The works of Luso-Brazilian authors about their economy were strongly influenced by foreign travelers and philosophers. One can hardly underestimate the international leverage of esteemed authors such as Captain James Cook, Abbé Raynal, and Adam Smith whose work greatly influenced the Brazilian scientific community and whose opinions were echoed throughout the European intellectual world. Unfortunately for the Brazilians, these well-known scientists did not rate the Portuguese colony very highly. Indeed, most European travelers and intellectuals looked down upon Brazil, defining its population as "indolent" and any trade obstruction as illegitimate. Not only have these visitors been a source for future historians, they also set the tone of the debate for the issues for the next two centuries.

None of these distinguished foreigners had good words for the governance, society, and economy of Brazil. Captain Cook, for instance, made some very negative descriptions of Rio de Janeiro after he was virtually sent away from the Brazilian capital by the viceroy. Cook declared that the rule over Brazil was "very despotic in fact," the population of Rio de Janeiro were too devotional since "they pray and sing their hymns with such vehemence, that in the night they were very distinctly heard on board the ship," that women in Rio de Janeiro "make less difficulty of granting personal favours, than those of any other civilized country in the world," and that the greater part of the land is "wholly uncultivated, and

${ }^{18}$ Azeredo, Ensaio, 1992, and Souza, Textos, 1993

${ }^{19}$ On Gregório de Matos see Hansen, Sátira, 1989; on Tomás Antônio Gonzaga see Gonçalves, Gonzaga, 1999. 
little care and labour seem to have bestowed upon the rest". ${ }^{20}$ Captain Cook was joined by other Europeans scholars who were equally critical of Brazilian society.

One of the most widely read books on colonial societies was that of the enlightened Abbé Raynal. The first print of his Philosophical and political history of the establishment and commerce of the Europeans in the Indies was in 1770 , a standard work for all the elites and has remained so ever since. Like Captain Cook, Raynal looked disdainfully upon the economy of colonial Brazil, and the French philosopher paid particular attention to smuggling and the poor Portuguese administration. Raynal comments that Brazil is a rich colony, and that the Portuguese were the first to open up trade to Africa and the Orient. ${ }^{21}$ Unfortunately, Portugal had fallen into decline for two main reasons. The first are regulations of commerce through monopolies, which strengthened after the Lisbon earthquake of 1755 that decreased commerce and stimulated illegal trade. The second is the dependency of the Portuguese economy on the British, which weakened Portugal's economy. Raynal argues that the British administration has Portugal and its colonies in its grips, and the only way out of this situation is to open up Brazilian trade to all foreign nations, and especially to France. Raynal never visited Brazil, so he worked with travel accounts as his sources. This is obvious in his judgment on colonial Brazil, since many a foreigner expressed her/himself in similar terms. However, the political economy of Raynal's work is new, and it was soon to be mimicked by generations of Brazilian and European intellectuals.

The celebrated Scottish philosopher Adam Smith thought along to the same lines as Abbé Raynal. He had similar thoughts on the political economy of Portugal, Brazil and their relations with Great Britain. His Inquiry into the Origins of the Wealth of Nations was published only three years after Abbé Raynal's historical and philosophical history, at a time when the relations between Britain and Portugal came under scrutiny. Adam Smith argued against the mercantilist principles of his time. He stated that Britain's close economic relationship with Portugal worked out negatively for the former. Smith reconsidered the advantages of the famous Methuen treaty of 1703 , in which Britain promised to import wine from Portugal at a lower price than Portugal's competitors, in exchange for Portugal importing British textiles at a lower price than its competitors. ${ }^{22}$ Contemporaries and historians have always considered this treaty as the basis for British economic power over Portugal, since Britain was able to

${ }^{20}$ Hawkesworth, Account, 1773, pp. 28-32

(1770, pp. 397-416.

${ }^{22}$ On this treaty itself see Francis, Methuens, 1966 
import gold cheaply from Brazil as there was always a surplus on Britain's side that needed to be paid off. Smith, however, argued otherwise. He argued that the treaty was unnecessary, since Britain would have supplied textiles cheaper than its competition anyway, and now it was forced to import Portuguese wine..$^{23}$ Moreover, since Britain had a trading surplus with almost all European countries, gold would flow in its direction either directly from Portugal, or indirectly from other countries trading with Portugal.

Both Smith and Raynal had similar ideas: Portugal's economy was badly organized by its monopolies, trade liberalization would be good for all (especially for Britain and France), and this would end the oppressive economic stronghold that Portugal had over Brazil. Brazilians have followed the two examples of Raynal and Smith. They used Raynal's concept of economic and governmental exploitation by Portugal over Brazil, and they looked favorably on Smith's ideas on the opening of the Brazilian economy as a way to further progress and development.

Using the first generation of writers as a source, the second generation of positivist historians became sheer collectors of information. Historians of the colonial era depended on either local sources, their own experiences, or travel accounts. They freely copied one another in an age where copying other authors was an honor rather than an offense. With the prohibition of a printing press in Brazil -the necessity to have all publications approved by both secular and religious institutions- news from Brazil remained scarce. This changed with the transfer of power from Lisbon to Rio de Janeiro in 1808 and the subsequent opening of Brazilian borders to foreigners. The secretive mind-set disappeared and foreign interest in the country opened.

With this new philosophy, foreign historians gained a renewed interest in Brazilian history, generated new sources of information, and had access to other sources. The early part of the nineteenth century saw an increase of foreign travelers who were not limited to coastal cities, but who could visit the Brazilian interior by themselves. The French court painter Debret, the British visitor John Mawe, and the Swiss mining specialist Von Eschwege were among the many guests whose impressions of Brazil were printed, and whose books would be an important source on Brazil's economy and society for future generations of historians. ${ }^{24}$

The first comprehensive History of Brazil was written by the English poet Robert Southey, based on extensive research of official correspondence.

${ }^{23}$ Smith, Wealth, 2000, pp. 586-590.

${ }^{24}$ Eschwege, Pluto, 1833; Mawe, Travels, 1822. Both have been translated into Portuguese and are published by Livraria Itatiaia Editora ltda. 
Southey's book was based on "A collection of manuscripts not less extensive than curious, and which is not to be equaled in England. [...] The collection was formed during a residence of more than thirty years in Portugal, by the friend and relation to which this work is inscribed."25 Southey's friend and relation was Herbert Hill, reverend of the English nation in Lisbon, who remained Southey's sponsor through his life and who encouraged the poet to write a comprehensive history of Brazil. ${ }^{26}$

Southey's work reflects the conclusions of the official correspondence. The documentation is official, and they combined Raynal and Smith's ideas on the political economy of the Portuguese empire with those reflected in Portuguese administrators' reports. On the one hand, smuggling was a burden to the Portuguese treasury; on the other hand, extensive contraband networks reflected the Portuguese state's weakness to assert its authority over the Brazilian colony. Southey's view on contraband trade becomes most clear in his analyses of gold smuggling. Mimicking an eighteenthcentury document, Southey explained that smuggling gold dust was so profitable that it was hard to avoid. "But the traders into whose hands it [gold dust] passed debased it so greatly, that if it found its way to the Mint, there was usually a loss of ten or twelve per cent upon the assay, in addition to the twenty per cent deducted for duty." ${ }^{27}$ Southey's views become more philosophical and he starts to explain smuggling from a moral point of view.

Among those persons who are trained up to consider the acquisition of riches as the great object of their lives (and this is always the scope of vulgar education) there will be a large proportion in every country who care little concerning the manner by which this object might be obtained. Fraudulent practices in the common course of trade, are but too frequent in countries where the standard of morality is higher than Minas Geraes: but no practice could be so gainful as that of clandestinely exporting gold; and less scruple is always felt in defrauding governments and corporate bodies, than in cheating individuals. ${ }^{28}$

Although Southey believed that illegal trade was caused by exceptionally low morality in the interior of Brazil, he also neatly pointed out that contraband trade was a more general phenomenon.

As foreigners investigated Brazil, so also did Brazilians start to acquire information abroad. Brazil's elite looked at France and the United States

${ }^{25}$ Southey, History, 1822, vol. 1, p. xxiv

${ }_{27}$ Ibid., vol. $1, \mathrm{p}$.

Ibid., vol. 3, p. 594 
as an example for its future development. These more "advanced" countries paved the way for Brazilians for cultural and economic development. As admiration for "the West" increased, so did historians seek for their materials in these countries. During the nineteenth century, Brazilian gentlemen historians started the foundation of the discipline by copying documentation in foreign archives, and by publishing them through national and local historical institutions such as the National Library, and the Historical and Geographical Institutes. ${ }^{29}$ Several historians were diplomats such as Adolpho Varnhagen, and they visited French, British, Dutch, Portuguese, and Spanish archives in order to acquire crucial documentation about the new nation's past. ${ }^{30}$ Still today, historians profit from the nineteenth and early twentieth century positivist actions of reproduction of documentation where the reader by him/herself could interpret the past. ${ }^{31}$ The copied documents consisted mainly of diplomatic records as well as official correspondence sent by the viceroy and others to Lisbon. In Portugal, the originals could be found in the Overseas Archives, which housed the documentation of the Overseas Council (Conselho Ultramarino). The first substantial inventory of this documentation was made by Eduardo Castro e Almeida and subsequently published in the Annals of the National Library in Rio de Janeiro. ${ }^{32}$ Varnhagen and Almeida's work formed the foundation for historians on colonial Brazil up to the late twentieth century.

Varnhagen's História do Brasil remains a treasure for Brazilianists. In the same tradition others wrote copious Brazilian histories. Pedro Calmon is a wonderful example of this continuation from Southey and Varnhagen. His six volume work chronicles Brazil's past using the same type of documentation as Varnhagen, supplemented by sources acquired through his own tour of Portugal. ${ }^{33}$ Calmon's work is a well researched work, reflecting the same interpretations viewing Brazilian history from the viewpoints of governors, rebellions, and occurrences described in the

${ }^{29}$ See the index of the journal of Revista do Instituto Historico e Geográfico Brasileiro, year 159, vol. 400, Jul/Sept. 1998. Unfortunately, it only covers the institute in Rio de Janeiro.

Another such historians was José Higino Duarte Pereira a historian from Pernambuco who ordered the transcription of many Dutch documents for the historical and archeological institule in Recife. Gonsalves, Impo, 1998, pp. 182-184, Gro to supplemented this research and at this monent through "Operação Resgate." For more information on this project see <http://www.resgate.unb.br/rhistorico.htm〉 Aruivo Publico Mineiro, Anais ar Biblioteca Nacional, Documentos Históricas, and the Documentos Interessantes para a História de São Paulo.

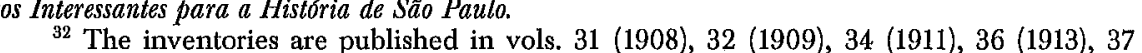
(1914), $39(1916), 46(1924), 50(1928)$, and 71 (1951). These are the reference years, which does

not always coincide with the year of publication. See vol. $100(1980)$ for an index.
${ }^{3}$ Calmon, História, 1959. 
official correspondence and travel accounts, but he distinguishes himself from the nineteenth-century authors by using a more thematic approach. He classifies contraband trade as part of general commerce. His observations anticipate the dependência (dependency) historians, who claim that through the commercial Treaty of Methuen (1703) Portugal became the intermediary in the colonial commerce, where Brazil delivered its goods (legally or illegally) to England. ${ }^{34}$ According to Calmon, England profited greatly from Brazilian products, yet this trade brought only marginal advantages to Portugal and Brazil, as the king invested his profits in palaces and the export of Brazilian products (esp. gold and diamonds) gave colonists the incentive to explore its interior. ${ }^{35}$ Brazil's underdevelopment was thus explained by the relative backwardness of Portugal.

Brazil's underdevelopment was followed up by resistance against the Portuguese repressive regime, the main theme of the "romantic" third generation of Brazilian historians. This could not be an acknowledgment of Portuguese superiority over Brazil, but rather how Brazilians were able to overcome Portuguese pressure through smuggling. These stories did not come from the administrative correspondence; rather they were part of local oral histories and thus of the "real Brazil." Two examples of these romanticized stories are those of Xica da Silva and Dona Beija, two legendary women who beat the system. ${ }^{36}$ Their stories demonstrate the cruelness of colonial exploitation, as well as the incompetence and corruption of officials and the local nomenclature, and the valiant struggle of the commoner. In the case of diamond mining, Feliciano dos Santos asserted that the contractor João Fernandes Oliveira, was all powerful and that his will was obeyed by everyone in the mines. However, his slave-turned-lover Francisca (Xica) da Silva could manipulate the contractor into doing whatever she preferred. Only Pombal, the Secretary of State in Portugal, could overcome the contractor's power and he forced the rich and powerful Oliveira to return in Lisbon. ${ }^{37}$ This historiography built a new national identity, where Brazilian resilience was represented through the mulatta and the underdog. The idea of contraband as form of resistance remains, even though the oral histories themselves have been proven to be factually incorrect. ${ }^{38}$

$$
{ }_{35}^{34} \text { Ibid., vol. 4, p. } 1211 .
$$

Ibid

${ }^{36}$ Dos Santos, Memórias, 1956, p. 166, n. 28. "Nós os sabemos da tradição e testemunho de pessoas respeitáveis e fidedignas, que tivemos o trabalho a consultar, que os ouviram dos contemporâneos de João Fernandes, que os conheceram e foram testimunhas oculares"; in the same tradition see the works of Vasconcelos, especially, Vida, 1988, as well as Salles, Anna, w.d.

${ }^{37}$ Dos Santos, Memórias, 1956, pp. 160 y 164. ${ }^{38} \mathrm{Junnia}$ Ferreira Furtado corrected these myths using both official correspondence and
notarial archives in her Ferreira Furtado, Chica, 2003. 
After World War II, the fourth generation of Brazilian historians started to use a more economic approach. Rather than explaining illegal trade though administrative failure, it was portrayed as a part of economic systems that were underdeveloped. For this approach, economic historians continued to use the diplomatic and official records, combining them with eighteenth century colonial thinkers such as Abbé Raynal and Adam Smith, while being influenced by Marxist thinking on cycles of economic development. ${ }^{39}$ The most influential historian of this period was Caio Prado Jr., whose economic history explained that: "It is the so called 'colonial pact' destined to reserve the national market of every country more and more for the products of its respective colonies, and the maritime commerce under its flag. This national exclusivism put Portugal and its colonies in a very bad position; without a navy [... and without a large national market, it restricted the exportation of its colonial goods." ${ }^{40}$

The absence of extensive manufacturing, no big market, and no shipping prevented the economic development of Portugal and its colonies. The subsequent system of monopolies prevented industrialization of the Iberian country and its overseas possessions. Without a free market economic development would become more difficult. ${ }^{41}$

Caio Prado Jr.'s ideas are close to those of the dependency theorists. His work was continued by Brazilian historians during the military dictatorship. ${ }^{42}$ These academics investigated both quantative and qualitative materials, and found renewed evidence to confirm Caio Prado's conclusions. José Jobson de Andrade Arruda was a quantitative historian who backed up his findings with balances of trade from the late eighteenth and early nineteenth century. Considering this early statistical material, he discovered that Brazil even had a positive balance of trade with Portugal, which Arruda saw as clear evidence of the failure of the "old colonial system". ${ }^{43}$ Corcino Medeiros dos Santos used similar material, aided by early statistics found in Brazilian archives which described the flow of commerce in Rio de Janeiro and other main port cities. ${ }^{44}$ His work was a supplemented by Virgílio Noya Pinto and Michiel Morineau who used materials from French consuls in Lisbon and French newspapers to estimate the value of the annual fleets as well as the gold production in Brazil. ${ }^{45}$

${ }^{99}$ The classical work on economic cycles is Azevedo, Épocas, 1988

${ }^{10}$ Prado, Historia, 1987, p. 79

${ }^{41}$ Ibid., p. 92 .

${ }^{42}$ Particularly influencial was the work of the the sociologist and later president of Brazil,

Cardoso, Dependência, 1970.

14 Medeiros, Rin, 1993

${ }_{45}$ Noya, Ouro, 1979; Morineau, Incroyables, 1985. 
Although these historians were not the first to use statistical material, they were the first to analyze them in depth, and Arruda even used the numbers to calculate an estimate of the amount of illegal trade in tobacco. ${ }^{46}$ Unfortunately, almost all these historians took the eighteenth-century statistics on face value, as the Portuguese historian José Pedreira was able to point out. ${ }^{47}$

Caio Prado Jr. found his strongest disciple in Fernando Novais who wrote the most widely read book on dependency and crisis of the colonial system in Brazil. ${ }^{48}$ Novais made an in-depth analyses of the materials from Lisbon, and especially the many reports on the decay of the Brazil trade and increase of illegal trade by Brazilian and Portuguese administrators. Using this material, Novais could not but confirm that the Portuguese colonial system had entered a stage of crises at the end of the eighteenth century. According to Novais, the phenomenon of illegal trade can not be seen without understanding the Old Colonial System, because "it is subservient to the total of the economic relations between the economies of the centers and the peripheries". ${ }^{49}$ By principally using sources from the Portuguese administration, Novais and his disciples came to the conclusion that the Old Colonial system was powerful enough to undermine economic development in Brazil. ${ }^{50}$ However, these ideas came increasingly under scrutiny as Brazilianists were starting to analyze agency beyond the administrative elites.

In Brazil, a fifth generation of social/cultural/economic historians started to integrate the sources and the conclusions of their colleagues interested in slavery and gender issues. Historians of slavery have long considered the idea that slaves had leverage in their unequal relationship with their owners. However, the nature of this relationship had not been codified until these historians started to use testaments and documentation of religious organizations just like social historians. ${ }^{51}$ Especially crucial was the publication of an inventory of all archives with documents related to slavery in commemoration of the centennial of its abolition in $1988 .^{52}$ This opened up a wide array of new sources that could provide both more reliable answers to old questions, and that allowed Brazilian historians

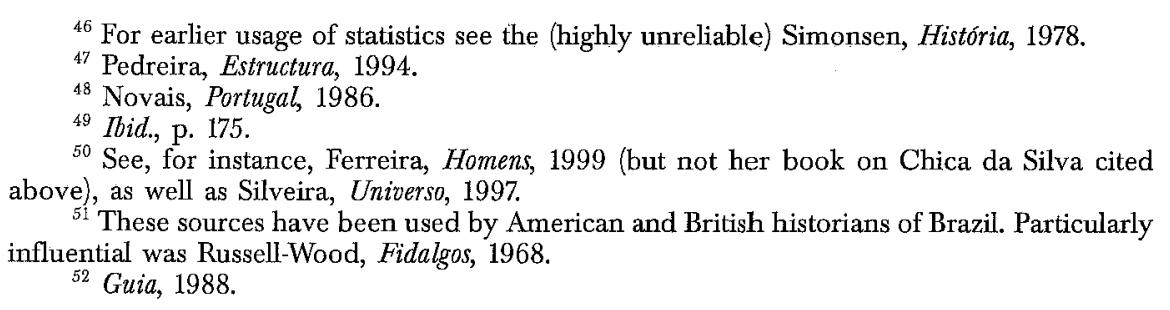


to reconsider the nature of their own economy beyond the dogma of colonial exploitation. ${ }^{53}$

One of the first to use notarial records to trace commercial transactions was João Fragoso. ${ }^{54} \mathrm{He}$ argued that the slave trade was fundamental in building capital in Brazil, thereby for the first time denying Portuguese hegemony of commercial activities. Increasingly, Brazilian historians such as Manolo Florentino and Luiz Felipe de Alencastro start to view the Brazilian maritime economy from a Southern Atlantic perspective, and let loose the idea that it was only run by major export products such as sugar, gold, and diamonds. ${ }^{55}$ At the same time, Portuguese historians started to assert the role of their country in the Brazil trade. Jorge Pedreira demonstrated that not only British products but also Portuguese textiles had a large market share in Brazil..$^{56}$

This new generation of Brazilian historians with ties to European and North American education, are now training more "home grown" graduate students than ever. ${ }^{57}$ Rather than moving to France, England, or the United States these students are using state universities in all parts of Brazil. Graduate students are now exploring local archives in their vicinity from Rio de Janeiro to Tocantins. ${ }^{58}$ Unfortunately, too many masters and doctoral theses have remained sheltered from a national audience, as local publications are not well distributed. Nevertheless, national and regional ANPUH (National Association of University Professors in History) meetings have been instrumental in providing their research a wider academic public and uncovering the importance of "the other" Brazil in and beyond the colonial centers. ${ }^{59}$

${ }^{53}$ For two recent overviews of Brazilian historiography see Russell-Wood, Slavery, 2002, pp. XIII-LIII -a Portuguese translation with an updated bibliography is in press; Schwartz, "Somebodies", 1996.

${ }^{54}$ Ribeiro, Homens, 1992. wrote their comments in Arcaísmo, 1996.

${ }^{6}$ See the debate between Pedreira, "Growth", 2000, pp. 839-864, and Andrade, "Decadence", 2000, pp. 865-878 and between Pedreira, "Contraband", 2001, pp. 739-744, and

Pijning;, "New", 2001, pp. 733-738. she did course work in Paris and post-graduation with A. J. R. Russell-Wood; João Fragoso was tuart Schwartz. In general, the late twentieth generation holds close contacts with North American, French, British, and Portuguese historians.

${ }^{58}$ Just one example of an excellent thesis based on local archival sources is Macêdo, "Trajetóra", 1990.

${ }^{59}$ North American historians such as Mary Karasc h David McCrery, Hal Langfur, and Judy Bieber have started to elaborate on their studies of "the frontier" in Goís and Minas Gerais where they formed to llaborate on their studies of "he frontier" in Goiás and Minas Estudos Humanidades. Revista da Universidade Catolica de Goiás, 29 (special vol.), march 2002. Master's students from state universities start to get enrolled in the University of São Paulo's graduate programs and elaborate on their work on the Brazilian interior. 
These new historiographic tendencies might easily give the impression that the metropolis asserted no influence whatsoever over the colony. Historians need to reevaluate old and new evidence to reassess the importance of colonial rules over Brazil, and this is particularly important if one studies illegal trade. Rather than explaining all in terms of resistance and exploitation, we need to think about accommodation, appropriation, and incorporation. The newest wave of historians of colonial Brazil is grasping with that situation, by rereading old sources, by researching uncovered foreign and domestic archives, and by studying previously unknown areas. ${ }^{60}$ As Brazil is facing a world of balancing national interests to international relations, where nothing is either completely red or blue, this is bound to happen soon.

\section{BiBLIOGRAFÍA}

Alencastro, Luiz FeliPe De, Trato dos viventes. Formação do Brasil no atlântico sul, São Paulo, Companhia das Letras, 2000.

Andrade Arruda, José Jobson de, O Brasil no comércio colonial, São Paulo, Editora Ática, 1980.

"Decadence or Crisis in the Luso-Brazilian Empire: A New Model of Colonization in the Eighteenth Century", Hispanic American Historical Review, vol. 80 , no. 4, november 2000 , pp. 865-878.

ANTONIL, ANDRÉ JoÃo (pseud.), Cultura e opulência das drogas do Brasilh, Andrée Mansuy ed. and transl., Paris, Institut des Hautes Études de l'Amérique Latine, 1965.

AZEREdo COUTINHO, José JoAQuim DE, Ensaio económico sobre o comércio de Portugal e suas colónias 7794, Lisbon, Banco de Portugal, 1992.

Azevedo, J. Lúcio de, Épocas de Portugal económico, Lisbon, Clássica Editora, $4^{\text {th }}$ ed., 1988 ( $1^{\text {st }}$ ed. 1928).

Bernstein, Harry, The Brazilian Diamond in Contracts, Contraband and Capital, Lanham, New York, University Press of America, 1986.

Bicalho, Marda Fernanda, A cidade e o império. O Rio de Janeiro no século XVIII, Rio de Janeiro, Civilização Brasileira, 2003.

BIsNut, Roger (ed.), Arte de Furtar, Lisbon, Imprensa Nacional Casa da Moeda, 1991.

Borba de Morats, Rubens, Bibliographia Brasileira: Rare Books about Brazil Published from 1504 to 1900 and Works by Brazilian Authors of the Colonial Period, Los Angeles and Rio de Janeiro, Livraria Kosmos Editada, 1983, 2 vols.

BRADFORD BURNS, E.." "The Intellectuals as Agents of Change and the Independence of Brazil, 1724-1822," in A. J. R. RUSSELL-WOOD (ed.), From Colony to Nation. Essays on the Independence of Brazil, Baltimore, Johns Hopkins University Press, 1975, pp. 211-246.

${ }^{60}$ Bicalho, Cidade, 2003; Langfur, "Uncertain”, 2002; Pijning, "Contrabando", 2001 


\section{$82 \quad$ Ernst Pijning}

Calmon, Pedro, História do Brasil, Rio de Janeiro, Livraria José Olympio, 1959, 6 vols. Cardoso, Fernando Henrique, Dependência e desenvolvimento na América Latina; ensaio de interpretação sociologica, Rio de Janeiro, Zahar, 1970.

Couto, Diogo do, O Soldado Prático, M. Rodrigues Lapa ed., Lisbon, Sá da Costa, 3a. ed., 1980.

Dos Santos, Joaquim Felício, Memórias do Distrito Diamantino da Comarca do Sêrro Frio, Belo Horizonte, Edições o Cruzeiro, $3^{\text {rd }}$ ed., 1956 ( $1^{\text {st }}$ ed. 1868).

ESCHWEGE, W. L. VON, Pluto brasiliensis. Eine reihe von abhandlungen über brasiliens golddiamanten und anderen mineralischen reichtum, Berlin, G. Reimer, 1833.

Frrnandes Brañd̃o, Ambrósio, Dialogues of the Great Things in Brazil, Frederick Holden Hall (ed. and transl.), Albuquerque, University of New Mexico Press, 1987

Ferreira Furtado, Júnia, Homens de negócio. A interiorizaşão da metropole e do comércio nas minas setecentistas, São Paulo, Hucitec, 1999.

Chica da Silva e o contratador dos Diamantes. O outro lado do mito, Rio de Janeiro, Companhia das Letras, 2003.

Fragoso, Jox̃o and Manolo Florentino, $O$ arcaísmo como projeto. Mercado atlântico, sociedade agrária e elite mercantil no Rio de Janeiro c. 1790-c.1840, Rio de Janeiro, Sette Lettras, $2^{\text {nd }}$ ed., 1996.

Francis, A. D., The Methuens and Portugal, 1691-1708, Cambridge, Cambridge University Press, 1966.

GARCIA FLORENTINO, MANOLO, Em costas negras. Uma historia do trafico de escravos entre a Africa e o Rio de Janeiro (séculos XVIII e XIX), Rio de Janeiro, Arquivo Nacional, 1995.

GonÇALVES, ADEiTo, Gonzaga, um poeta do illuminismo, Rio de Janeiro, Nova Fronteira, 1999.

Gonsalves de Mello, José ANTÔNIo, Tempo de Journal, Recife, Fundação Joaquim Nabuco/Editora Massangana, 1998.

Guia brasileiro de fontes para a história da Africa, da escravidão negra e do negro na sociedade actual: fontes arquivistas, Rio de Janeiro, Arquivo Nacional, 1988, 2 vols.

HANSEN, JOÃo ADOLFo, A sátira e o engenho. Gregorio de Matos e a Bahia do século XVII, São Paulo, Editora Schwarcz, 1989.

HAWKESWORTH, JOHN (ed.), An Account of the Voyages Undertaken by the Order of his Present Majesty for Making Discoveries in the Southern Hemisphere, and Successively Preformed by Commodore Byron, Captain Wallis, Captain Cartenet and Captain Cook, in the Dolphin, the Swallow, and the Endeavour: Drawn up from the Journals which ere Kept by the Several Commanders, and from the Papers of Joseph Banks esq, London, printed for W. Stranhan and T. Cadell, 1773, vol. 2.

Kagan, Richard L., "Prescott's Paradigm: American Historical Scholarship and the Decline of Spain", American Historical Reviere, vol. 101, no. 2, 1996, pp. 423-446.

LANGrUR, Hal, "Uncertain Refuge: Frontier Formation and the Origins of the Botocudo War in Late Colonial Brazil", Hispanic American Historical Revieve, vol. 82, no. 2, May 2002,pp. 215-256. 
MACẼDo FILHA, MaURÍDES BATISTA DE, "A trajetóra do diamante em Goiãs", master's thesis, Universidade Federal de Goiás, 1990.

Magalhães GÂndavo, Pero De, História da Provincia Santa Cruz a que vulgarmente chamamos Brasil, Lisbon, Biblioteca Nacional, 1984 (reprint from 1576).

MAWE, JoHN, Travels in the Interior of Brazil, London, Longman, Hurst, Rees, Orme and Brown, 1822.

Medeiros dos Santos, Corcino, O Rio de Janeiro e a conjuntura atlântica, Rio de Janeiro, Expressão e Cultura, 1993.

Memórias económicas da Academia Real das ciências de Lisboa, para o adiamento da agricultura, das artes, e da indústria em Portugal, e suas conquistas, Lisbon, Banco de Portugal, 1990-1991, vols. 1-5.

Miller, Shawn W., Fruitless Trees. Portuguese Conservation and Brazil's Colonial Timber, Stanford, Stanford University Press, 2000

Morineau, Michel, Incroyables Gazettes et fabuleaux Méteaux. Les retours des trésors americains d'après les Gazettes Hollandaises (XVIt-XVIIIe siècles), London/Paris, Cambridge University Press/ Maison des Sciences de l'Homme, 1985.

Novais, Fernando A., Portugal e Brasil na crise do antigo sistema colonial (1777-1808), São Paulo, Editora Hucitec, $4^{\text {th }}$ ed., 1986 ( $1^{\text {st }}$ ed. 1979).

NoYa Pinto, Virgílo, O ouro brasileiro e o comércio anglo-português, São Paulo, Ed. Nacional, 1979.

Pedretra, Jorge Miguel Viana, Estructura industrial e mercado colonial. Portugal e Brasil (1780-1830), Lisbon, Difel, 1994.

"From Growth to Collapse: Portugal, Brazil, and the Breakdown of the Old Colonial System, 1750-1830", Hispanic American Historical Review, vol. 80, no. 4, November 2000, pp. 839-864.

, "Contraband, Crisis, and the Collapse of the Old Colonial System", Hispanic American Historical Review, vol. 81, no. 3-4, August-November 2001, pp. 739-744.

PIjNING, ERnst, "Controlling Contraband: Mentality, Economy and Society in Eighteenth-Century Rio de Janeiro", Ph. D. dissertation, Baltimore, Johns Hopkins University, 1997.

"A New Interpretation of Contraband Trade", Hispanic American Historical Reviere, vol. 81, no. 3-4, August-November 2001, pp. 733-738.

, "Contrabando, ilegalidade e medidas políticas no Rio de Janeiro do século XVII", Revista Brasileira de História, 2001, vol. 21, no. 42, pp. 397-414.

Prado JR., Caio, Histôria econômica do Brasil, São Paulo, Editora Brasiliense, $35^{\text {th }}$ ed., $1987\left(1^{\text {st }}\right.$ ed. 1945).

RAYNAL, ABBE, Histoire philosophique et politique des établissemens $\mathbb{F}$ du commerce des européens das les deux Indes, Amsterdam, 1770, vol. 3

RIBEIRO FrAGOSO, JOÃo Luís, Homens de grossa aventura: accumulação e hierarquia na praça mercantil do Rio de Janeiro (7790-7830), Rio de Janeiro, Arquivo Nacional, 1992.

RusseLL-Wood, A. J. R., Fidalgos and philantropists. The Santa Casa da misericóridia of Bahia, 1550-1755, Berkeley, University of California Press, 1968 

Saldes Coelho, Maria Sylvia, Anna d'Africa, Belo Horizonte, Editora Santa Edwiges, w.d.

Schwartz, StuarT B., "Somebodies and Nobodies in the Body Politic: Mentalities and Social Structures in Colonial Brazil", Latin American Research Review, no. 31, 1996, pp. 113-134.

SIIVA LISBOA, JOSÉ DA, Escritos Económicos Escolhidos, 1804-1820, Lisbon, Banco de Portugal, 1993, 2 vols.

Silvetra, MARco ANTONIo, 0 universo do indistincto. Estado e sociedade nas minas setecentistas (1735-1808), São Paulo, Hucitec, 1997.

Simonsen, Roberto C., História economica do Brasil (1500/1820), São Paulo, Companhia Editora Nacional, $8^{\text {th }}$ ed., 1978.

Smith, AdAM, The Wealth of Nations, Edwin Cannan (ed.), New York, the Modern Library, 2000.

SouTHEY, RoBERT, History of Brazil, New York, Lenox Hill Publishers, $2^{\text {nd }}$ ed., 1970, $\left(1^{\text {st }}\right.$ ed. 1822).

SouzA COUTINHO, D. RoDrigo DE, Textos políticos, económicos e financeiros, 1783-1811, Lisbon, Banco de Portugal, 1993, 2 vols.

TyLer, JOHN W., Smugglers and Patriots. Boston Merchants and the Advent of the American Revolution, Boston, Northeastern University Press, 1986.

Vaifas, Ronaldo (ed.), Dicionário do Brasil colonial (1500-1808), Rio de Janeiro, Objetiva, 2000.

VASCONCELos, AGRIPA, A vida em flor de Dona Beia. Romance do ciclo do povoamento nas Gerais, Belo Horizonte, Editor Itatiaia, ${ }^{\text {th }}$ ed., 1988.

WEBER, DAVID J., The Spanish Frontier in North America, New Haven NC, Yale University Press, 1992.

WinIuS, GEORGE D., The black legend of portuguese India. Diogo do Couto, his contemporaries and the "Soldado Prático", New Delhi, Concept Publishing Company, 1985. 


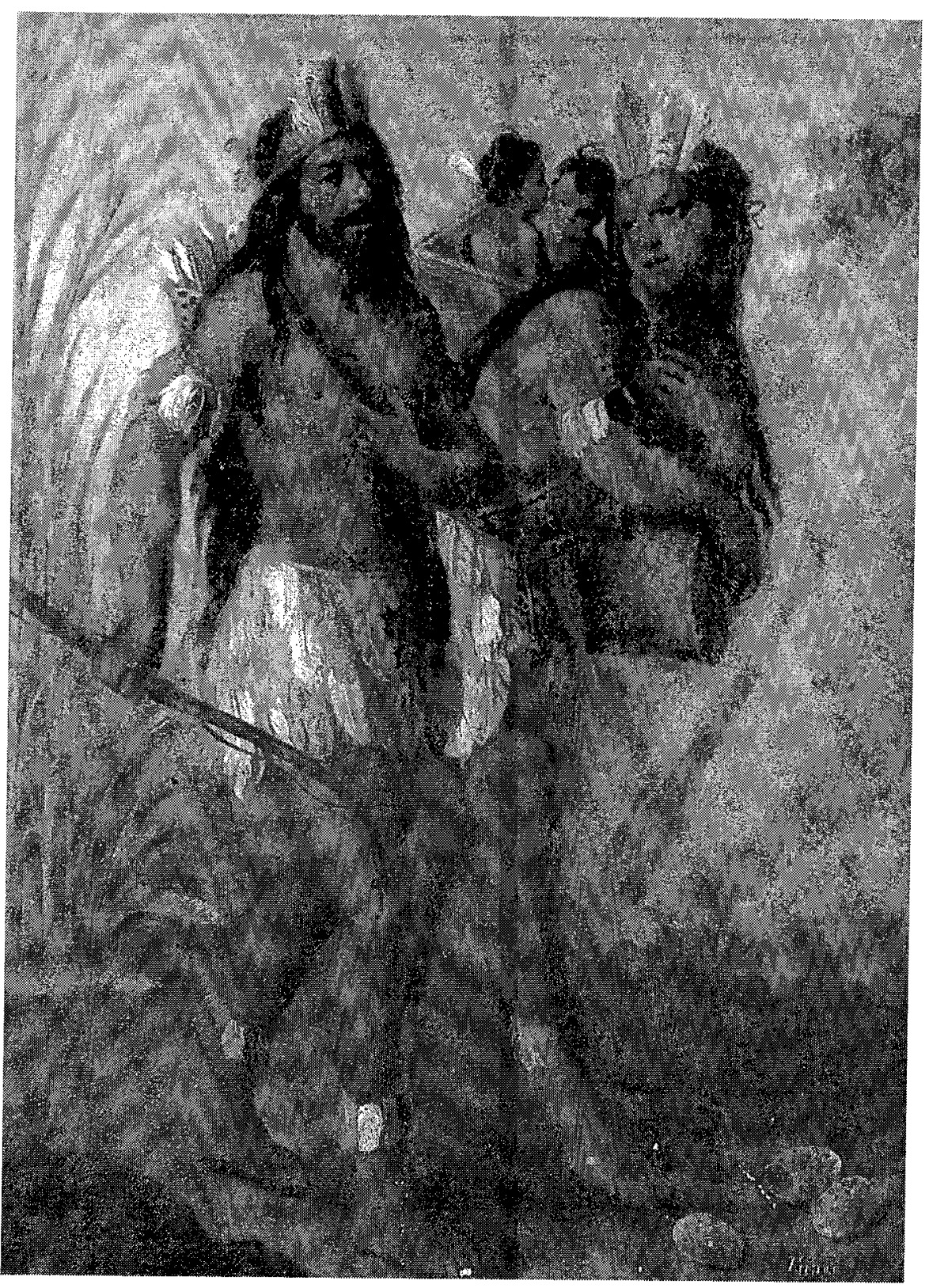

Tomada de Luis Navarro García (coord.), Historia general de España y América, t. xI-1, América en el siglo X7III. Los primeros Borbones, Madrid, Ediciones Rialp, 1983, p. 251. 